\title{
POLA HIDUP SEHAT MAHASISWA MAGISTER MANAJEMEN PENDIDIKAN ISLAM INSTITUT PTIQ JAKARTA PERSPEKTIF GERAKAN MASYARAKAT HIDUP SEHAT (GERMAS)
}

\author{
Siskandar $^{1}$, Ahmad Zain Sarnoto ${ }^{2}$, Etika Nailur Rahma ${ }^{3}$ \\ Institut PTIQ Jakarta ${ }^{1}$, Institut PTIQ Jakarta ${ }^{2}$, \\ Institut PTIQ Jakarta ${ }^{3}$, \\ siskandar2000@yahoo.com ${ }^{1}$, ahmadzain@ptiq.ac.id ${ }^{2}$, \\ nailurrahmaetika1@gmail.com ${ }^{3}$
}

\begin{abstract}
The purpose of this study is to analyze healthy life self-management of master students and to find a Healthy Lifestyle Perspective Healthy Living Movement (GERMAS). The method used in this research is a qualitative descriptive with fenomenolgy approach. While the data collected in the ways of interviews, observation, documentation and data analysis techniques in the ways of Data Reduction, and Data Display. Based on the results of the research, it is known that self-management is a healthy life of PTIQ Jakarta management master students, mostly done well by students, by implementing a Healthy Lifestyle according to the steps of the Healthy Living Society Movement (GERMAS), Informants who do not apply a Healthy are due to several factors, both factors that influence the formation of attitudes and behavior formation.
\end{abstract}

Keywords: Healthy Lifestyle, Students, Healthy Living Community Movement (GERMAS)

\begin{abstract}
ABSTRAK
Tujuan dari penelitian ini adalah menganalisa manajemen diri hidup sehat mahasiswa magister dan menemukan Pola Hidup Sehat Perspektif Gerakan Masyarakat Hidup Sehat (GERMAS). Metode yang digunakan dalam penelitian ini adalah deskriptif kualitatif dengan pendekatan fenomenologi. Metode pengumpulan data pada penelitian ini menggunakan metode wawancara, observasi, dokumentasi dan teknik analisis data berupa Data Reduction (Reduksi Data), dan Data Display (Data Penyajian). Berdasarkan hasil penelitian diketahui bahwa manajemen diri hidup sehat mahasiswa Magister Manajemen PTIQ Jakarta, sebagian besar dijalani dengan baik oleh mahasiwa, dengan diterapkannya Pola Hidup Sehat sesuai langkah-langkah Gerakan Masyarakat Hidup Sehat (GERMAS), Informan yang tidak menerapkan Pola Hidup Sehat disebabkan karena beberapa faktor baik itu faktor yang mempengaruhi pembentukan sikap maupun pembentukan perilaku.
\end{abstract}

Kata kunci: Pola Hidup Sehat, Mahasiswa, Gerakan Masyarakat Hidup Sehat (GERMAS) 


\section{PENDAHULUAN}

Lembaga Pendidikan berkontribusi kepada pengembangan sumber daya manusia,(Sarnoto, 2017) dan salah satu aspek yang terpenting dalam kehidupan manusia adalah Kesehatan. Kesehatan itu mahal harganya dan menjadi kebutuhan dasar bagi manusia. Meskipun kesehatan sangat penting, manusia di bumi ada yang mengadopsi kebiasaan buruk dalam hidupnya, melakukan pola hidup yang sembarangan sekalipun itu orang yang berpendidikan, yang jika dilihat dari pengetahuannya, mahasiswa kedokteran sekalipun yang seharusnya lebih paham akan kesehatan. Pada penelitian yang dilakukan Khoiriyah bisa dilihat bagaimana mahasiswa yang berkecimpung di kesehatan, terkonfirmasi melakukan pola hidup tidak sehat, dilihat dari persennya terbanyak dalam hal jarang melakukan kegiatan fisik $(61,4 \%)$, dilanjutkan dengan makan yang tidak sehat, pola tidur yang tidak teratur dan paling sedikit persennya pada kebiasaan merokok (Cuma 4,9\%).(Khoiriyah, 2008)

Tingkah laku yang tidak memenuhi syarat hidup sehat, berupa aktivitas fisik yang tidak sesuai dengan prinsip hidup sehat, ditemukan pula pada mahasiswa FK Untan (Fakultas Kedokteran Universitas Tanjungpura).(Suharto et al., 2013)

Kegiatan yang seringkali bertentangan dengan prinsip hidup sehat, akan berdampak tidak baik pada masyarakat dan juga akademisi, sedikit besar dapat mempengaruhi trust penduduk suatu lingkungan, dalam hal ini juga akademisi, jika ketika mahasiswa fakultas kedokteran berkiprah dan mensosialisasikan ilmunya di bidang kesehatan tersebut.

Penelitian yang dilakukan M.Nur Wahyudi, menyebutkan terdapat kebiasaan masyarakat yang ingin melakukan segalanya serba cepat, mudah dan sedikit bergerak, istilahnya serba pragmatis. Gaya hidup pragmatis, dengan mengkonsumsi makanan berpengawet dan tidak sehat, makanan yang dimasak juga tidak terlepas dari unsur yang membuat makanan menjadi gurih dan sedap karena dikasih penyedap rasa dengan berbagai merk penyedap makanan yang beredar di pasaran, tentu saja keberadaan bahan pengawet tersebut akan menyebabkan penyakit dalam jangka pendek dan dalam jangka panjang juga, dengan adanya penyakit tidak menular (PTM) dan sebagainya. Jelasnya makanan olahan tersebut tidak baik bagi kesehatan. Mengkonsumsi makanan cepat saji, kurang baik bagi kesehatan, karena makanan tersebut tidak bagus bagi kesehatan karena kandungan yang ada didalamnya baik pengawet dan bahan yang tidak alami berbahaya bagi tubuh manusia.(Wahyudi, 2015) Sebagian besar kebiasaan yang tidak sehat akan dirasakan saat usia tua nanti, dan seseorang akan sadar betapa sangat berharganya kesehatan, dimana dengan sehat manusia bisa melakukan apapun, bisa bekerja untuk menari nafkah dan belajar maupunn berkarya bagi mahasiswa maupun masyarakat umumnya. Adapun untuk mendapatkan kehidupan sehat yang baik tidak hanya diam saja, tapi harus diupayakan, sehingga di dapat kualitas hidup yang baik, sehingga penyakit dapat dicegah dan kalaupun terkena penyakit bisa lebih dini diobati, sehingga kemungkinan sembuh akan lebih banyak. Karena itu diperlukan upaya untuk mewujudkan pola hidup sehat, dengan menerapkan manajemen kesehatan diri dengan baik, untuk menciptakan kebiasaan hidup yang baik dan akan mendapatkan badan yang bugar penuh diliputi kesehatan.

Mahasiwa yang mengatur gaya hidupnya, bagaimana seseorang berperilaku hidup sehat, bisa di prediksi dari tubuh bugar dan sehat, utama juga lingkungannya yang mendukung dan bersih. Tapi juga berlaku sebaliknya jika 
seseorang berada di lingkungan yang kotor, tidak bersih yang mana lingkungan diliputi virus dan bakteri yang menjadi penyebab datang berbagai macam penyakit yang menjangkiti badan manusia, sehingga menderita penyakit. Melihat hal tersebut hendaknya mahasiswa menjaga diri dan memperhatikan kualitas kesehatannya, supaya mahasiswa mendapatkan kualitas kesehatan yang baik, sehingga mahasiswa bisa kuliah dan berkaya dengan baik dengan tubuhnya yang sehat. Diperlukan kesadaran yang tinggi, agar mahasiswa tetap berada dalam kondisi sehat, sadar melakukan perilaku hidup sehat dengan memanajemeni diri sendiri, merupakan aspek penting yang perlu dilakukan untuk menjaga kesehatan mahasiswa. Hal yang urgent perlu di implementasikan sebagai upaya pola hidup sehatnya. Untuk realisasinya di butuhkan manajemen kesehatan diri yang bagus bagi mahasiswa agar terwujud kualitas sehat bagi diri mahasiswa itu sendiri. Disini penulis hendak meneliti yang berkaitan dengan manajemen kesehatan diri mahasiswa Magister Manajemen PTIQ Jakarta. Sekaligus untuk mengetahui pribadi personal mahasiswa dalam konteks manajemen kesehatan, dan Bagaimana mahasiswa Magister Manajemen PTIQ Jakarta menjalankan gaya hidup yang baik ketika melakukan kegiatan-kegiatannya.

Dalam penelitian yang dilakukan oleh Erica Betseba di temukan permasalahan bahwa masih banyak mahasiswa yang tidak melakukan olahraga meskipun sudah tersedia fasilitas di kampus maupun lingkungan sekitar kampus. Universitas Sumatera Utara memiliki fasilitas olahraga diantaranya Jogging track biro rektor, GOR yang biasa dipakai untuk latihan dan pertandingan juga bisa dimanfaatkan sebagai Jogging track. Stadion Sepakbola yang biasa dipakai untuk latihan, pertandingan, even seremonial kegiatan bahkan even musik. Tempat bermain tenis, tempat main bola bas et, tempat untuk olahraga bola voli, serta. Lokasi untuk main Futsal yang biasa digunakan untuk latihan maupun bertanding. Pernyataan diatas juga terjadi pada mahasiswa Fakultas Kesehatan Masyarakat Universitas Sumatera Utara (FKM USU), ditengah padatnya aktifitas perkuliahan dan banyaknya tugas yang dimiliki mahasiswa FKM USU, menyebabkan pola hidup sedenter pada mahasiswa FKM USU. Tidak seimbangnya pola aktifitas fisik dapat mempengaruhi kebugaran mahasiswa FKM USU, yang dapat berdampak pada kesehatan dan kualitas belajar mahasiswa FKM USU.(Betseba, 2018)

Perilaku tidak sehat ditemukan pula pada mahasiswa kesehatan, meskipun presentasinya kecil. Hal tersebut dijumpai pada penelitian yang dilakukan Universitas Pelita Harapan pada tahun 2012 mengenai perbedaan perilaku sehat antara mahasiswa kesehatan menunjukan bahwa secara garis besar mahasiswa kesehatan memiliki perilaku kesehatan yang baik dibandingkan dengan mahasiswa non kesehatan. Variabel yang diteliti pada penelitian tersebut adalah kebiasaan merokok, alkohol dan kebiasaan makan mahasiswa dalam kondisi baik (masing-masing 95,1\%, 89,\%, 48,9\%).(Harapan, 2012)

Mahasiswa pascasarjana PTIQ sebagai akademisi yang konsentrasi dibidang agama, diharapkan mampu menerapkan kesehatan secara masif. Menurut Zohar dan Marshal Zohar, seseorang yang memiliki kecerdasan spiritual atau spiritual tinggi akan mampu mengendalikan diri sepenuhnya.(Sarnoto, 2014) Kecerdasan spiritual merupakan kecerdasan yang menempatkan perilaku dan hidup manusia dalam konteks makna yang lebih luas.(Rahmawati1 \& Sarnoto, 2020) Seseorang yang memiliki kecerdasan spiritual yang tinggi mampu memaknai hidup dengan memberi makna positif pada setiap peristiwa, masalah, bahkan penderitaan yang dialami sehingga mampu membangkitkan jiwanya, 
melakukan perbuatan dan tindakan yang positif, salah satunya tindakan tidak merokok.(Harapan, 2012).

Karena pentingnya Kesehatan ini, perlu adanya berbagai gerakan yang dikerjakan bersama-sama masyarakat secara luas, dalam hal ini mahasiswa juga melakukan yaitu salah satu gerakan yang kompeten dengan kesehatan di masyarakat disebut dengan Gerakan Masyarakat Hidup Sehat, Atas prakarsa Presiden RI diadakanlah Gerakan nasional yang disebut dengan Gerakan Masyarakat Hidup Sehat (GERMAS) yang mengedepankan upaya promotif dan preventif, tanpa mengesampingkan upaya kuratif-rehabilitatif. Menurut Khairul Anam Didalam jurnalnya, Kalau melihat hitung-hitungan materi, mencegah adanya penyakit pastinya lebih murah apabila dibandingakan dengan biaya apabila seseorang mengalami sakit. Upaya supaya seseorang bisa terhindar dari berbagai macam penyakit, hendanya seseorang menjalani hidup sehat. Pola hidup sehat tersebut bagaimana seseorang melaksanakan tindakan yang baik dan menciptakannya serta menjauhi tingkah laku buruk yang merusak kesehatan. Adanya penyakit jantung, paru-paru, ginjal, stress dan beberapa penyakit tidak menular lainnya yang disebabkan perilaku yang buruk, tidak mengarah ke hidup yang sehat, dan itu yang seharusnya di jauhi. Kesehatan yang bermasalah dapat timbul saat ini akibat sikap yang tidak baik ditambah perilaku hidup yang tidak sehat. Sedangkan Perilaku Hidup bersih dan sehat adalah sekumpulan perilaku yang dipraktekkan atas dasar kesadaran sebagai hasil pembelajaran, yang menjadikan seseorang, keluarga, masyarakat dan mahasiswa khususnya mampu menolong dirinya sendiri (mandiri) di bidang kesehatan dan berperan aktif dalam mewujudkan kesehatan masyarakat. Rencana yang cermat dari pemerintah Indonesia, khusunya departemen kesehatan dalam upaya mendapatkan tujuan pembangunan yang salah satunya adalah terciptanya penduduk Indonesia sehat sejahtera.

Karena pentingnya Kesehatan ini, perlu adanya berbagai gerakan yang dikerjakan bersama-sama masyarakat secara luas, dalam hal ini mahasiswa juga melakukan yaitu salah satu gerakan yang kompeten dengan kesehatan di masyarakat disebut dengan Gerakan Masyarakat Hidup Sehat, Atas prakarsa Presiden RI diadakanlah Gerakan nasional yang disebut dengan Gerakan Masyarakat Hidup Sehat (GERMAS) yang mengedepankan upaya promotif dan preventif, tanpa mengesampingkan upaya kuratif-rehabilitatif.

Namun demikian dalam mensosialisasikan Gerakan Masyarakat Hidup Sehat (GERMAS), sebagai upaya untuk menjalani pola hidup yang lebih sehat, tidak terlepas dari sikap dan perilaku manusia. Dimana sikap manusia merupakan predictor yang utama bagi perilaku (tindakan) sehari-hari, meskipun masih ada faktor-faktor lain, seperti faktor lingkungan dan keyakinan seseorang.

\section{METODE PENELITIAN}

Penlitian ini menggunakan metode kualitatif, adapun tema dalam penelitian ini adalah Pola Hidup Sehat Mahasiswa Magister Manajemen Pendidikan Islam Institut PTIQ Jakarta

Dalam penelitian kualitatif dapat mengelompokkan beragam sumber data jenis maupun posisinya, mulai dari yang paling nyata sampai sumber yang samarsamar, mulai yang primer sampai sekunder.(Sukmadinata, 2010) beberapa cara mendapatkan data dalam penelitian ini. Cara mendapatkan data sangat bermacammacam. Bisa memakai cara wawancara mendalam, pengamatan, dan dokumentasi dalam karya ilmiah ini. 


\section{HASIL PENELITIAN}

Dari hasil penelitian informan memperoleh hasil bahwa di Institut PTIQ tidak ada peraturan tersurat tentang program GERMAS. Dari pihak Institut memberikan saran untuk dosen dan mahasiswa saja. Selanjutnya Dari hasil wawancara ditemukan adanya keempat tingkatan sikap mahasiswa magister terhadap pola hidup sehat diatas sesuai dengan teori Notoatmojo, adanya 4 tingkatan sikap yakni: Menerima (receiving), Merespon (responding), Menghargai (valuing) dan bertanggung jawab (responsible).

Ada dua hal yang diteliti untuk mengetahui sikap mahasiswa megister dalam menyikapi hidup sehat mahasiswa, yaitu tingkatan sikap, adapun faktor yang mempengaruhi pembentukan sikap menurut Azwar ada enam hal yang diteliti untuk mengetahui sikap mahasiswa magister dalam menyikapi hidup sehat GERMAS, yakni: Pengalaman pribadi, kebudayaan, orang lain yang dianggap penting, Media massa, Lembaga Pendidikan dan Lembaga Agama dan Pengaruh Faktor emosi.

Dari hasil pengamatan penulis dapat dianalisa bahwa perilaku kesehatan mahasiswa magister manajemen, baik itu ditinjau dari faktor perilaku (behavior causes) dan faktor di luar perilaku (non-behavior causes), sebagaian besar berperilaku bijak dalam kesehatan masing-masing mahasiswa. Perilaku yang merupakan pola hidup sehat informan ini tidak terbentuk dengan sendirinya. Dalam penelitian ini, berdasarkan hasil penelitian adanya perilaku mahasiswa didasarkan dari beberapa faktor, yang dibagi menjadi tiga yaitu faktor predisposisi, pendukung dan pendorong. Yang termasuk kedalam predisposisi adalah pengetahuan, kepercayaan, sikap, keyakinan, nilai dan tradisi, dan yang temasuk kedalam Pendukung adalah yang terwujud dalam lingkungan fisik, yaitu sarana prasarana tempat olah raga dan makanan bergizi, dan yang temasuk kedalam faktor pendorong adalah sikap dan peran petugas kesehatan yang merupakan kelompok referensi dari perilaku masyarakat dan peraturan Undangundang yang berlaku.. Berdasarkan hasil penelitian, salah satu mahasiswa menyatakan bahwa perilaku hidup sehatnya dipengaruhi oleh pengetahuan, kepercayaan dan tradisinya, faktor tersebut masuk ke dalam predisposisi, dia juga mendapatkan pengaruh dari fsktor yang mendukung dan mendorong perilaku hidup sehatnya, baik dengan adanya sarana prasarana, tersedianya buah dan sayur yang mudah didapatkan, meskipun justru tidak ditemukan di kantin kampus, yang justru secara tidak langsung mempengaruhi bagaimana bagaimana perilaku Mahasiswa terhadap Pola Hidup Sehat.

Berdasarkan hasil penelitian wawancara mendalam dengan mahasiswa yang dilakukan baik secara online dan offline diketahui bagaimana mahasiswa memanajemeni diri sendiri dalam berpola hidup sehat perspektif Gerakan Masyarakat Hidup Sehat (GERMAS), demikian juga ketika mahasiswa ada yang tidak mampu memanajemeni diri dan ada mahasiswa yang mampu mengurus dan mengorganisasikan waktu dengan baik, sehingga tugas atau pekerjaan bisa diselesaikan dan keputusan yang tepat bisa di ambil, dan menjadi pribadi yang bisa memanajemen hidup sehat pribadinya dengan baik dan tentunya yang juga sejalan dengan konsep kesehatan yang terkandung dalam Al-Quran maupun AlHadist. Konsep ini sejalan dengan kehidupan yang dipraktikkan oleh Rasulullah SAW. Beliau mempraktikkan hidup bersih, keluhuran budi, dan penghormatan pada sesama. (Akhmad Shunhaji, 2020). 
Hal ini sesuai dengan teori Healey yang menyatakan bahwa kesehatan yang baik secara keseluruhan bisa dirawat apabila aktivitas fisik dilakukan dan dia merupakan faktor yang utama. Manfaat kesehatan yang berarti bisa dimiliki jika seseorang menjadi aktif secara fisik, dengan mengurangi resiko berbagai penyakit kronik, mengatur berat badan dan mengembangkan kesehatan mental bisa dibantu. Memanajemen kondisi jangka panjang bisa dilakukan dengan dibantu beraktivitas fisik, seperti artritis dan diabetes tipe 2, dengan mereduksi efek dari kondisi tersebut dan kualitas hidup penderitanya ditingkatkan.(J, 2013) Dampak yang dirasakan informan bila tidak rutin menetapkan aktivitas fisik, yang dirasakan informan seperti badan mudah capek, badan terasa pegal-pegal, badan terasa berat, tidak fresh, mudah ngantuk dan badan menjadi kaku.

Informan merasakan dampaknya karena tidak rutin dalam menerapkan aktivitas fisik., sebagaimana yang diungkapkan oleh ustadz DD dan juga seorang mahasiswa magister, ketika diwawancara: "Rasanya kayak mudak capek gitu mbak kan saya dari rumah ke kampus perjalanan 45 menit jadi kalau seminggu nggak olahraga gitu jadi cepat capek terus pegel-pegel."(DD, n.d.). Diatas sama juga untuk wawancara yang dilakukan terhadap mahasiswa magister berkaitan dengan tujuh langkah Gerakan Mahasiswa Hidup sehat (GERMAS) yang lainnya.

\section{PEMBAHASAN}

Begitupun pada mahasiswa magister manajemen, implememntasi kegiatan GERMAS tidak semuanya dilaksanakana. Kegiatan dari kegiatan kampus khususnya yang mengarah untuk implementasi Germas seperti melakukan aktivitas fisik baik dengan gerakan fisik termudah sepeti jalan kaki menuju kampus, gerakan dalam sholat, mahasiswa makan buah sayur, tidak konsumsi alkohol, cek kesehatan secara berkala, lingkungan bersih dan sehat harus dijaga dan memakai jamban. Namun demikian tidak semuanya mahasiswa melaksanakan tujuh langkah GERMAS Tersebut, dikarenakan sarana komunikasi yang mendorong untuk penyiaran kegiatan dan informasi mengenai GERMAS belum tersedia. Kendala di implementasi Germas salah satunya dikarenakan kesibukan dari mahasiswa Mahasiswa tersebut baik sibuk di perkuliahan ataupun di pekerjaan yang lainnya. Hal ini terkait dengan teori yang berkaitan dengan Pola Hidup Sehat ditinjau dari Perubahan Perilaku, yaitu Teori Lawrence Green: Predisposisi, pendukung, pendorong. Demikian pula terkait dengan teori Snehandu B. Karr: adanya niat, dukungan sosial masyarakat sekitar, Terjangkau informasi, adanya informasi, adanya otonomi membuat keputusan, adanya situasi dan kondisi sehingga bisa bertindak.

Berdasarkan hasil penelitian wawancara mendalam dengan mahasiswa yang dilakukan baik secara online dan offline diketahuai bagaimana mahasiswa mampu memanajemeni diri sendiri dalam berpola hidup sehat perspektif Gerakan Masyarakat Hidup Sehat (GERMAS), baik beraktivitas fisik, konsumsi buah dan sayur, tidak merokok, tidak alkohol, cek kesehatan, kebersihan lingkungan dan menggunakan jamban. demikian juga ketika mahasiswa ada yang tidak mampu memanajemeni diri dalam hidup sehat dan ada mahasiswa yang mampu mengatur dan mengorganisasikan waktu dengan baik, sehingga akan mampu menyelesaikan tugas pekerjaan dan dapat mengambil keputusan dengan tepat, dan menjadi individu yang mampu memanajemen hidup sehat dirinya dengan baik dan tentunya yang juga sejalan dengan konsep kesehatan yang terdapat dalam kitab suci maupun Hadist. 


\section{KESIMPULAN}

Melihat hasil penelitian dan pembahasan penelitian tentang Pola Hidup Sehat Mahasiswa Magister Manajemen Pendidikan Islam Institut PTIQ Jakarta Perspektif Gerakan Masyarakat Hidup Sehat (GERMAS), Peneliti menganalisis Manajemen diri hidup sehat mahasiswa Magister Manajemen PTIQ dan menemukan Gerakan Masyarakat Hidup Sehat (GERMAS) yang sesuai untuk mahasiswa Manajemen Pendidikan Islam, dapat disimpulkan bahwa:

1. Sikap mahasiswa magister terhadap Pola Hidup Sehat Perspektif Gerakan Masyarakat Hidup Sehat (GERMAS) sebagian besar menujukkan sikap menerima, merespon, menghargai dan bertanggung jawab terhadap sikap yang telah di ekspresikan dan diungkapkan mahasiswa magister.

2. Mahasiswa mengapresiasi bahwa Pola Hidup Sehat diperlukan untuk mendukung berjalannya aktifitas mahasiswa di kampus, dengan sehat mahasiswa bisa melakukan aktivitas yang padat dengan konsdusif.

3. Sikap mahasiswa magister manajemen terhadap Pola Hidup Sehat sebagian besar dipengaruhi oleh: pengalaman pribadi, kebudayaan, orang lain yang dianggap penting, media masa dan lembaga pendidikan dan agama.

4. Perilaku hidup sehat mahasiswa magister dipengaruhi beberapa faktor, dan dari hasil penelitian dari hasil observasi dilapangan sebenarnya sikap dan perilaku sehat mahasiswa diatas memang tidak terlepas dari faktor-faktor yang mempengaruhi sikap dan perilaku mahasiswa magister tersebut.

Mahasiswa Magister sebagian besar sudah melaksanakan Pola Hidup Sehat, meskipun belum ada peraturan tertulis mengenai Gerakan Masyarakat Hidup Sehat (Germas), tetapi sudah ada himbauan kepada mahasiswa untuk menerapkan program Germas dalam kehidupan sehari-hari. Program Germas yang sudah diterapkan oleh mahasiswa magister, yaitu aktivitas fisik, budaya konsusmsi buah dan sayur, tidak merokok, tidak mengkonsumsi alkohol, cek kesehatan secara berkala, kebersihan lingkungan dan menggunakan jamban.

\section{DAFTAR PUSTAKA}

Betseba, E. (2018). Gambaran perilaku mahasiswa FKM USU dalam pencegahan penyakit tidak menular terhadap pemanfaatan fasilitas healthy center di FKM USU tahun 2018. Medan: karya ilmiah.

Harapan, U. P. (2012). Hubungan Perilaku Kesehatan antar Mahasiswa Dengan Mahasiswa Non Kesehatan. Universitas Pelita Harapan.

J, H. (2013). Physical Activity and Fitness. Thirroul: The Spinney Press.

Khoiriyah. (2008). Studi deskriptif perilaku hidup sehat mahasiswa kesehatan dan non kesehatan di Universitas Diponegoro Semarang. Universitas Diponegoro Semarang.

Rahmawati1, S. T., \& Sarnoto, A. Z. (2020). Kecerdasan Spiritual Perspektif AlQur' an. Madani Institute, 1(3), 1-14.

Sarnoto, A. Z. (2014). Kecerdasan Emosional Dan Prestasi Belajar: Sebuah Pengantar Studi Psikologi Belajar. In Profesi (Vol. 4).

Sarnoto, A. Z. (2017). Sumber Daya Manusia Dalam Pendidikan. Madani Institutte, 6(2). https://www.scribd.com/doc/97542011/Sumber-DayaManusia-Dalam-Pendidikan

Shunhaji, Akhmad., (2020). Syariat Pendidikan Nilai Kehidupan, dalam Jurnal Andragogi 2 Vol 2 Tahun 2020

Suharto, Tejoyuwono, A. A. T., \& Khatan, M. I. (2013). Gambaran Perilaku 
Merokok, Pola Makan, Perilaku Aktivitas Fisik Dan Pola Tidur Mahasiswa Fakultas Kedokteran Universitas Tanjungpura. Universitas Tanjungpura.

Sukmadinata, N. S. (2010). Metode Penelitian Pendidikan. Bandung: remaja Rosyda Karya.

Wahyudi, M. N. (2015). Pola Hidup Sehat dalam Perspektif Al-qur`an. Universitas Islam Negeri Walisongo. 